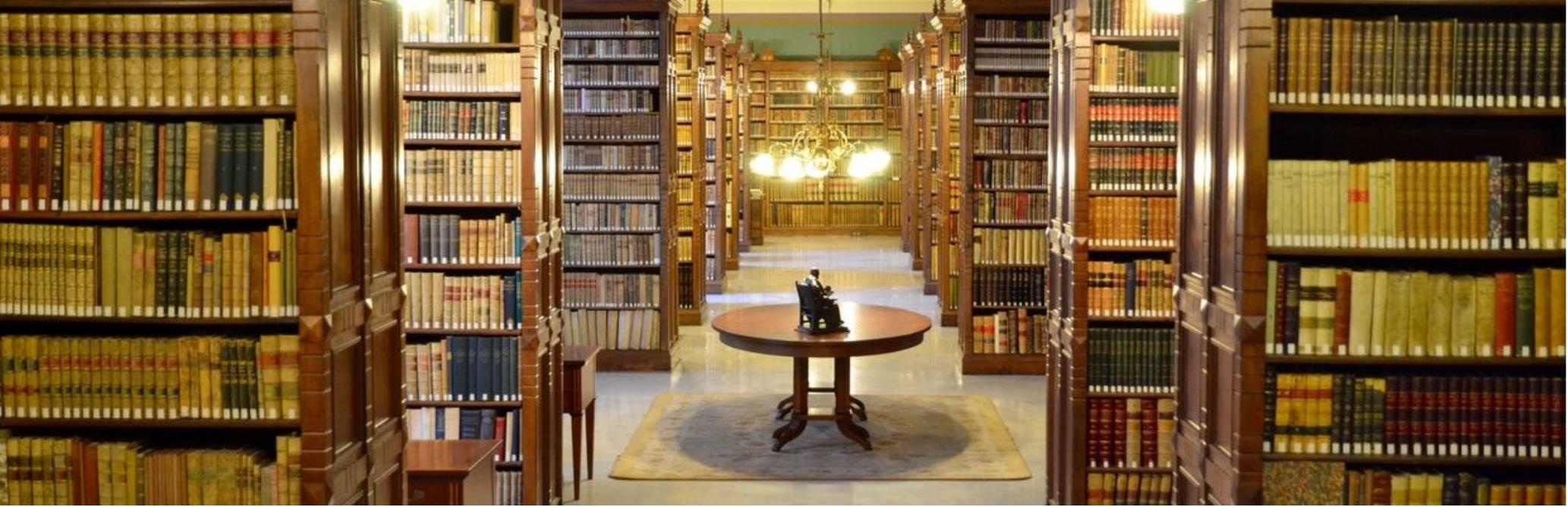

\title{
Editorial Volume 7, Issue 3
}

$\begin{aligned} \text { Authors: } & \text { María Fernanda Sandoval } \\ \text { Submitted: } & \text { 24. June } 2020 \\ \text { Published: } & 6 \text {. July } 2020 \\ \text { Volume: } & 7 \\ \text { Issue: } & 4 \\ \text { Affiliation: } & \text { Albert-Ludwigs-Universität Freiburg, Germany. } \\ \text { Languages: } & \text { English } \\ \text { Keywords: } & \text { Editorial, Josha Journal, May - June } 2020 \\ \text { Categories: } & \text { News and Views } \\ \text { DOI: } & 10.17160 \text { /josha.7.4.693 }\end{aligned}$

\section{Abstract:}

Dear JOSHA readers, once again we find ourselves saying goodbye and closing another wonderful issue! This bi-monthly issue is full of wonderful articles, including two of the candidates and possible winners of the 2020 Demetrios Award. In addition, we are re-packaging this section with new information that is useful to you and important to us, such as the new button to make your donation to the journal. On the other hand, don't miss the opportunity to visit our social media and get to know us from the Instagram gallery and the Facebook wall. Remember that you can comment on the articles and also provide your star ranking. 


\section{EDITORIAL}

VOLUME 7, ISSUE 3

Dear JOSHA readers, once again we find ourselves saying goodbye and closing another wonderful issue! This bi-monthly issue is full of wonderful articles, including two of the candidates and possible winners of the 2020 Demetrios Award. In addition, we are re-packaging this section with new information that is useful to you and important to us, such as the new button to make your donation to the journal. On the other hand, don't miss the opportunity to visit our social media and get to know us from the Instagram gallery and the Facebook wall. Remember that you can comment on the articles and also provide your star ranking.



Expanding the Network EL GATO Y LA CAJA \& JOSHA FOR THE SAME

„In the constant and ambitious search to bring more science to more places, break the language barrier, reduce inequalities and collaborate in evidence-based and empathetic decision-making, we found a communication project on the other side of the Atlantic that shares our spirit".

El Gato y La Caja.

\section{ABOUT OUR SOCIAL MEDIA}
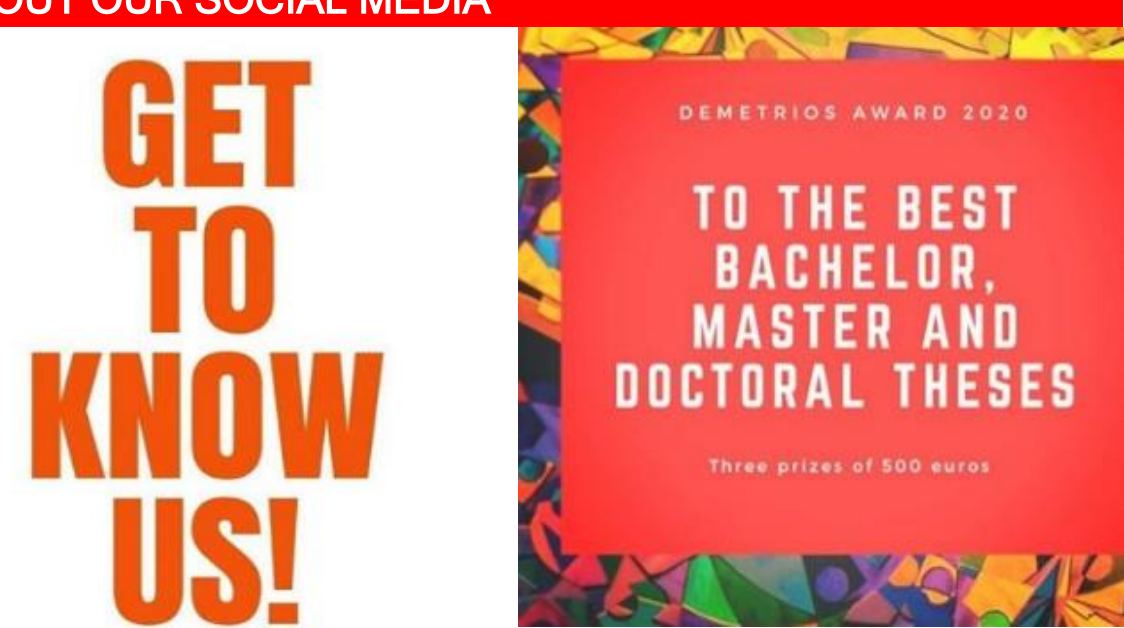

New in the list of Goals

GET TO KNOW THE JOSHA TEAM

We want to show you who is working behind JOSHA, the founders and co-founders as well as some members of the Editorial team.

On Instagram you will soon know their names and some of what they have done so far. Stay tuned to discover more about this new facet of the journal.

\section{Anual DEMETRIOS Award 3 PRIZES OF 500 EURO TO THE BEST THESES}

For the categories BACHELOR, MASTER and DOCTOR THESIS.

Our editors will make the selection and the theses of the winners will be published in JOSHA and can be referenced with their DOI number!

Send your work to admin@joshaarchive.org until August 30, 2020 and be part of this event! 


\section{JOSHA in all languages \& all over the world!}

This editorial contains articles from Russia, Argentina, Nigeria, Venezuela, Spain, Kosovo, Italy, and Germany, in for 4 different languages! Our May and June stats show a rapid elevation in number of views and downloads. Thank YOU!

\section{"We want to stay strong}

\section{for the knowledge!"}

\section{YOUR DONATION FOR JOSHA Journal / IASHA Academy}

Once again we celebrate the mission of JOSHA to offer its library services as a modern version of the Library of Alexandria. As a non-profit organization we have been able to provide scholarships to significantly support the careers of many students, artists, and young scientists from all around the world. Our openaccess journal lays out a forum where they can present their archievements. There, you can value their presentations and follow-up on the impact of your donation.

Today we are announcing a new button on our website through which you can support us.

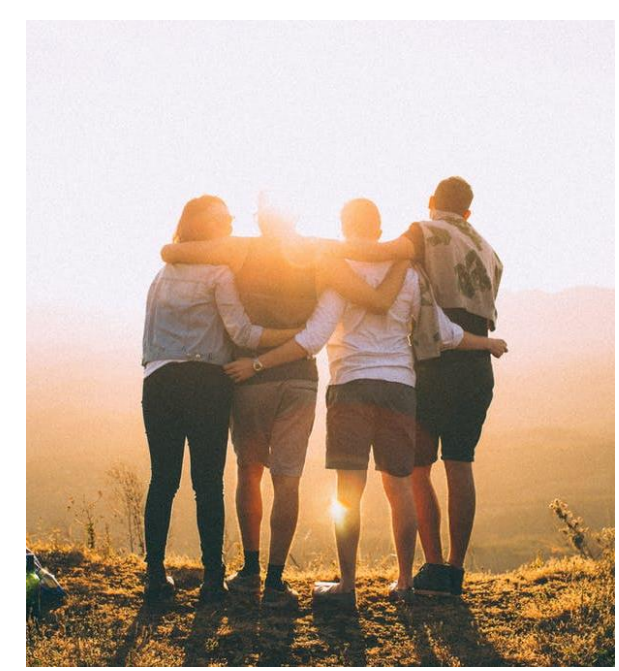

With your donation you set a sign of philantropy and help to continue our mission to support the future careers of young gifted people, especially during the time of the Corona Pandemic.

We are happy to carry on a successful way with all your support and hope to have a wonderful summer overflowing with endless interesting articles from all over the world. Together, we have achieved so much exile in such a short time. Therefore, we thank you and promise to continue to work to connect more authors around the world and continue to share important knowledge, because the

knowledge that is not communicated is wasted knowledge! 
The Editorial Board and everybody at JOSHA would like to thank our readers and authors for supporting this project. We wish all our readers a joyful reading experience at JOSHA!

Maria Fernanda Sandoval on behalf of the JOSHA Team

Table of content: http://josha-journal.org/en/issues

VOLUME: 7, ISSUE: 3

Bujar Q. Bajçinovci, Mejreme Bajçinovci, COVID-19 in Kosovo: Point from an Urbanite

Juan Pablo Escobar Fernandez, Juan Pablo Escobar Fernandez, ТЕХНИЧЕСКИЕ СРАВНЕНИЯ МЕЖДУ УЗКОЙ ШИРИНОЙ КОЛЕИ И СТАНДАРТОМ - Technical Comparisons between narrow Gauge and standard for electric Trains in Bogota

Luis Enrique Silva Vieira, En Torno al Concepto de Bildung en Gadamer - On the concept of Bildung in Gadamer

Franziska Buttgereit, Perfect Pitch

Timoteo Marchini , Corazón delator - The Tell-Tale Heart

Sebastián Vishnopolska, A libro abierto - An open book

Miguel Hernández-Bronchud, Alpha and Omega: from the Sagrada Familia to Placenta and Cancer

Sol Minoldo, Indebted Meritocracy

Sol Rodriguez R., Angel Martinez T, Marketing creativo como una forma efectiva de atraer clientes -

Creative Marketing as an effective Way to attract Customers

Mike Omilusi, Elite Fragmentation and Oligarchic Implosion in Nigeria's Democratic Space: A mere Stopgap or an Impetus to People's Emancipation?

Ana Belén Peñaherrera Pazmiño, Desarrollo de Canales de Microfluidica - Development of microfluidic Channels

Angel Martinez T, Sol Rodriguez R., Parámetros e indicadores que determinan una agricultura eficiente Parameters and Indicators that determine efficient Agriculture

Renate Penßel, The Recognition of Higher Education Diplomas and Qualifications

Carmine Cataldo, COVID-19 in Italia: una Percezione Amplificata del Rischio? 「COVID-19 in Italy: an amplified risk perception?]

Sol Minoldo, La meritocracia te la debo - Endebted Meritocracy 